\title{
RELAŢII PĂRINŢI - COPII, ÎNCOTRO? STUDIU COMPARATIV
}

\author{
Ana Fântână, Dina Popa*
}

\begin{abstract}
Education a soul, shaping it, does not only involve guiding it towards an informational system based on acquiring knowledge, but also towards a formative system of embracing the moral values. As the soul bears the image of God, school must use the religious element in order to stimulate the students conscience. The religious education has an important role in shaping one's character, but parents should also create a proper environment for producing a spiritual state favourable to morality. There have been major changes lately in the relationship between parents and children and they tend to increase as children grow up. Some of the causes have been identified in the research I starded in 2011 by aplying questionnaires to parents of secondary and high school students.

Both parents and teachers should be involved in establishinganefficient social communication. This is the reason why we have searched for concrete ways for achieving an efficient partnership between family and school.
\end{abstract}

Keywords: Education, parents, teachers, partnership, morality.

A educa un suflet, a-1 forma şi a-l convinge pentru un anumit fel de viaţă, nu înseamnă numai a-1 dirija spre un sistem informațional bazat pe asimilare, ci și spre unul formativ, al perceperii adevăratelor valenţe spirituale şi morale.

Pentru că sufletul are imprimat chipul lui Dumnezeu, școala promovând educarea sufletelor - trebuie să folosească în mod explicit elementul religios pentru consolidarea conştiinţei elevilor. Şi dacă şcoala îşi asumă funcţia educativă şi se străduieşte în a forma

\footnotetext{
*Ana Fântână, Teacher, at "Lucian Blaga" High School, Sebeş, Alba County, Romania; Dina Popa, Teacher at "Lucian Blaga" High School, Sebeş, Alba County, Romania.
} 
caractere, învăţământul religios este armura fundamentală a formării caracterelor $^{1}$, căci formarea bunelor deprinderi, exercitarea moralităţii nu pot deveni autentice fără producerea unei dispoziţii sufleteşti favorabile moralităţii ce îşi au începutul în familie.

$\mathrm{Cu}$ toate că acest fapt presupune asumarea responsabilităţii de către părinţi în educarea copiilor, în ultimul timp se constată modificări semnificative ale relaţiei părinţi-copii, care se amplifică pe măsură ce copiii cresc.

Cauzele sunt multiple, unele dintre acestea fiind identificate în cercetarea pe care am iniţiat-o în $2011^{2}$ prin administrare de chestionare părinţilor unor elevi din ciclul gimnazial şi liceal şi pe care am reluat-o în 2016 pentru a identifica o serie de tendinţe.

În scopul realizării unei comunicări sociale optime, este nevoie de implicare constructivă şi comunicare, atât din partea dascălilor cât mai ales din partea părinţilor, de aceea propunem câteva modalităţi concrete de acţiune pentru realizarea unui parteneriat familie - şcoală eficient, bazat pe convingerea că fiecare copil are nevoie de cei doi factori amintiţi.

\section{IPOTEZA ŞI OBIECTIVELE CERCETĂRII}

Datele cercetării au fost culese cu ajutorul chestionarului, elaborat pe baza următoarei ipoteze: părinţii, care neglijează din diferite motive aspectele ce ţin de problemele interioare ale copilului, aşteaptă ca aceste probleme să fie discutate de către copii la şcoală cu profesorul diriginte, în cadrul orei de religie cu profesorul / preotul sau cu psihologul şcolar.

Studiul de faţă îşi propune să compare date colectate în 2011 şi în 2016.

1 Bulacu, părintele Mihail, Pedagogia creştin-ortodoxă, Constanţa, Editura Şcoala Brâncovenească, 2009, p. 315.

2 Ana Fântână, Relaţia părinţi-copii, încotro? Analiza rezultatelor unei cercetări pe bază de chestionar administrat părinţilor, în Monica Opriş (coord), „Demersuri investigative în educaţia religioasă”, Alba Iulia, Editura Reîntregirea, 2010, p. 210-222. 
În anul 2011 au fost aplicate 772 chestionare în localităţile Sebeş, Cugir şi Cîmpeni, atât la şcoli generale cât şi la licee. Eşantionul a cuprins 77,97 \% femei şi 17,74 \% bărbaţi ${ }^{3}$. În 2016 au fost aplicate 350 chestionare în localitatea Sebeş şi satele din jur, atât la şcoli generale cât şi la licee, cu următoarea pondere: 77,5 \% femei şi 17,3 bărbaţi.

Chestionarul cuprinde 14 itemi de diferite tipuri, prin care am urmărit aspectele:

- $\quad$ cunoaşterea relaţiei părinţi - copii

- $\quad$ stabilirea modului în care părinţii se implică în viaţa şcolară si particulară a copilului

- $\quad$ aflarea punctelor sensibile ale acestei relaţii

- identificarea elementelor constitutive unei posibil plan de intervenţie pentru ameliorarea problemelor părinţi-copii.

\section{ANALIZA DATELOR}

Prima întrebare şi-a propus să afle părerea părinţilor la afirmaţia tot mai des întâlnită în spaţiul public: "Părinţii nu îşi cunosc copiii”. Răspunsurile arată faptul că doar o treime o consideră adevărată.

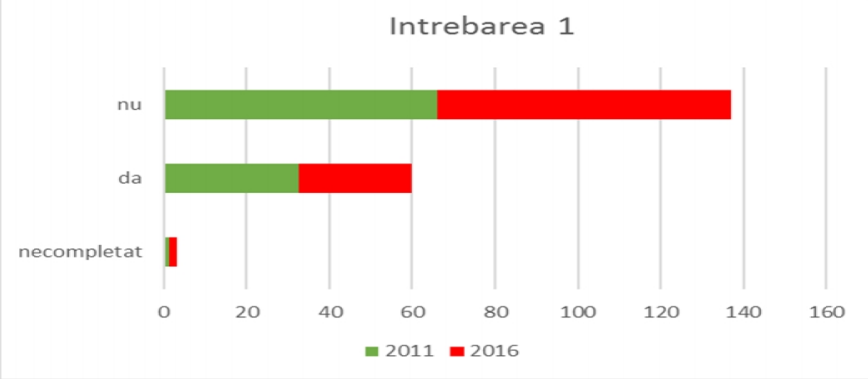

Fig. 1 Procentul părinţilor care consideră că expresia "Părinţii nu îşi cunosc copiii" este adevărată, în ceea ce îi priveşte

3 Ana Fântână, Relaţia părinţi-copii, încotro? Analiza rezultatelor unei cercetări pe bază de chestionar administrat părinţilor..., p. 211. 
În ambele cercetări principala motivaţie a adulţilor are la bază relaţia de încredere şi sinceritate dintre ei şi copii.

Întrebarea nr. 2 conţine o listă de nevoi ale copiilor formulate interogativ, părinţii fiind solicitaţi să aleagă cinci dintre ele de care se interesează în mod frecvent.

\section{Întrebarea 2}

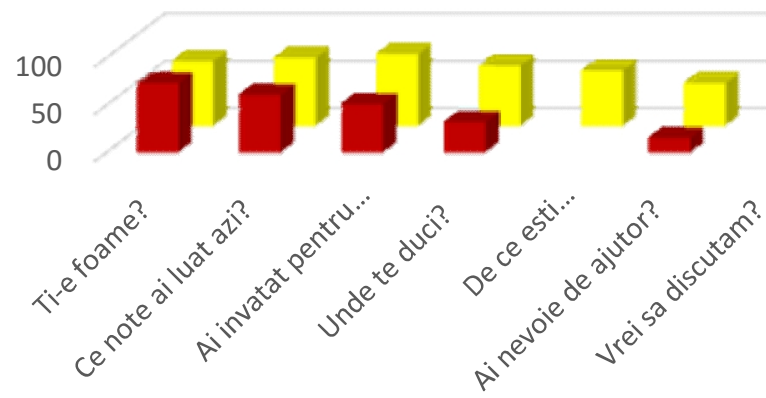

- $2011 \square 2016$

Fig. 2 Diagrame de comparaţie privind procentul întrebărilor puse în mod frecvent de părinţi copiilor lor, evidenţiat de cele două cercetări

Se observă din diagramă că predomină nevoile primare, ale celor legate de siguranţa unui loc de muncă obţinut în urma studiilor și a siguranței personale cum ar fi: Ți-e foame?, Ai învățat pentru mâine?. Într-o măsură mică, părinţii adresează întrebări care să răspundă nevoilor de încredere, dragoste, dezvoltare spirituală: De ce ești vesel/supărat?, Cum te ințtelegi cu colegii? și altele. În 2016 apar modificări semnificative de procente şi noi întrebări alese de părinţi, întrebări care vizează latura morală/interioară a copiilor.

Chiar dacă la prima întrebare, peste $60 \%$ dintre părinţi spun că relaţia cu propriul copil se bazează pe încredere şi sinceritate, procentul sincerităţii, ca însuşire a persoanei, este mic, aşa cum se observă din răspunsurile oferite la întrebarea nr. 3 ce urmărea 
însuşirile evidente la copilul personal. Şi alte însușiri au fost semnalate de părinți, într-adevăr cu procente mici, cum ar fi: credinţa, conștiinciozitatea, hărnicia, curajul.

\begin{tabular}{|l|l|l|}
\hline Însuşirile copilului & $\begin{array}{l}\mathbf{2 0 1 1} \\
\mathbf{\%}\end{array}$ & $\begin{array}{l}\mathbf{2 0 1 6} \\
\mathbf{\%}\end{array}$ \\
\hline politețe & 20,07 & 41,42 \\
\hline respect & 16,96 & 47,14 \\
\hline bunătatea & Sub 10 \% & 32,28 \\
\hline sinceritatea & Sub 10 \% & 29,14 \\
\hline
\end{tabular}

Tabelul 1 Procentul părinţilor privind însuşirile fiului/fiicei, în cele două cercetări

La întrebarea nr. 4 dacă simt nevoia să se informeze suplimentar despre ceea ce se întâmplă în viaţa fiului/fiicei lor părinţii au răspuns:

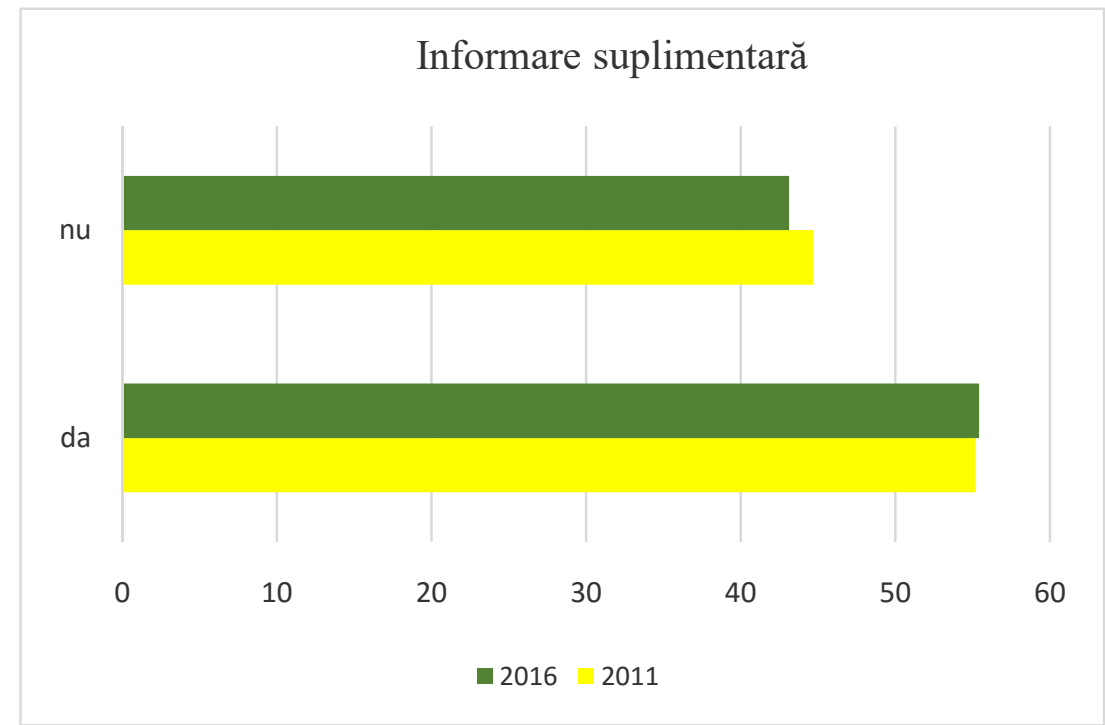

Fig. 3. Diagrama de comparație privind părerea părinţilor legată de informarea suplimentară 
Răspunsurile sunt motivate astfel: cei care au ales "Da" consideră că trebuie să îl cunoască mai bine, cei care au ales "Nu" au încredere în copil şi că acesta e sincer.

Referitor la timpul petrecut împreună cu copiii lor (întrebarea nr. 5) diagrama de structură din Tabelul 2 reflectă dificultăţi de comunicare dintre părinţi şi copii în 2011. Procentul crește în cazul părinţilor care petrece câteva ore pe zi cu copilul În 2016, părinţii devin mai responsabili şi mai conştienţi de rolul pe care îl au în viaţa copilului.

\begin{tabular}{|l|l|l|}
\hline Răspuns & \multicolumn{1}{|c|}{$\begin{array}{c}\mathbf{2 0 1 1} \\
\mathbf{\%}\end{array}$} & $\begin{array}{c}\mathbf{2 0 1 6} \\
\mathbf{\%}\end{array}$ \\
\hline zilnic, câteva minute & 58,41 & 32,4 \\
\hline zilnic, câteva ore & 24,22 & 58,1 \\
\hline la sfârşìt de săptămână & 11,26 & 3,2 \\
\hline doar când mă solicită & 6,11 & 6,4 \\
\hline
\end{tabular}

\section{Tabelul 2 Prezentarea comparativă a răspunsurilor celor doua cercetări la întrebarea 5}

Din răspunsurile la întrebarea nr. 6 am aflat că 87 \% dintre părinţi ştiu unde şi cum îşi petrece timpul copilul, însă în măsura în care aceştia le spun, pe când $9,8 \%$ nu îi întreabă pentru că au încredere în ei. Aceste răspunsuri vin ca o întărire a răspunsurilor date și la celelalte întrebări legate de tipul relației pe care părinții o au cu proprii copii. 
Știți unde și cum își petrec timpul liber copiii dvs?

$\mathrm{Nu}$, pentru ca am incredere in el/ea si nu intreb

Da, in masura in care imi spune el/ea

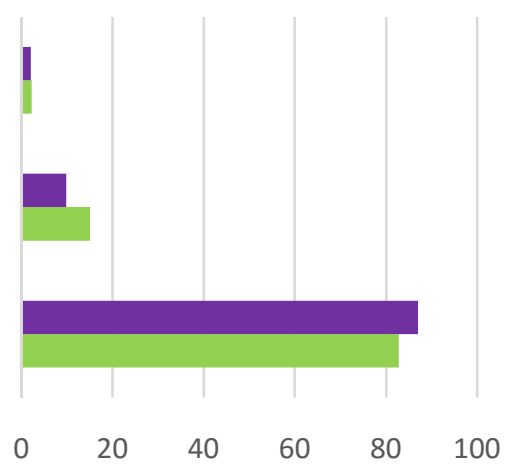

Fig. 4 Prezentare comparativă a răspunsurilor întrebării nr. 6 a celor două cercetări

Prin întrebarea nr. 7 am vrut să aflăm opinia părinţilor privind principalul motiv care i-ar putea îndepărta pe copii de ei, pe măsură ce aceştia cresc. Dintre motive amintim: lipsa de comunicare, conflictul dintre generații, anturajul acestea fiind cu cea mai mare pondere. Alte răspunsuri date de părinți ar fi: severitatea părinților, atenția scăzută a părinților, minciuna copiilor, lipsurile materiale inclusiv plecarea părinților în străinătate. 
Motivul îndepărtării copiilor de părinți

Nevoia de libertate

Lipsa de comunicare

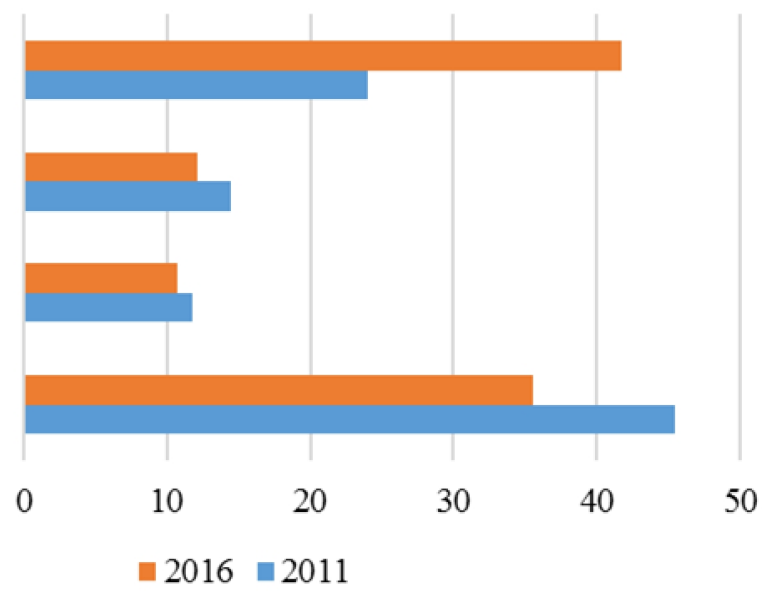

Fig. 5 Prezentare comparativă a răspunsurilor întrebării nr. 7 a celor două cercetări

Sau în tabelul de mai jos:

\begin{tabular}{|l|l|l|}
\hline Răspunsuri & $\begin{array}{l}\mathbf{2 0 1 1} \\
\mathbf{\%}\end{array}$ & $\begin{array}{l}\mathbf{2 0 1 6} \\
\mathbf{\%}\end{array}$ \\
\hline Lipsa de comunicare & 45,46 & 35,5 \\
\hline Nevoia de libertate & 11,78 & 10,7 \\
\hline Anturaj & 14,5 & 12,1 \\
\hline Alte răspunsuri & 23,99 & 41,7 \\
\hline
\end{tabular}

Tabelul 3 Prezentare comparativă a răspunsurilor întrebării nr. 7 a celor două cercetări

Din răspunsurile la întrebările nr 8 şi nr. 9 am întocmit o listă a lucrurilor care îi mulţumesc / nemulţumesc pe părinţi şi care sunt aceleaşi în ambele cercetări, diferă doar procentele

a. Lucrurile care îi mulţumesc pe părinţi în relaţia cu fiul/fiica lor 


\begin{tabular}{|c|c|c|}
\hline $\begin{array}{ll}\text { Lucruri } \\
\text { mulțumesc }\end{array}$ & $\begin{array}{l}2011 \\
\%\end{array}$ & $\begin{array}{l}2016 \\
\%\end{array}$ \\
\hline sinceritate & 22,27 & 20,7 \\
\hline comunicare & 11,65 & 13,6 \\
\hline cuminţenie & 18,39 & 12,7 \\
\hline încredere & 6,6 & 13,3 \\
\hline respect & 9,45 & 12,1 \\
\hline
\end{tabular}

Tabelul 4 Prezentare comparativă a răspunsurilor întrebării nr. 8 a celor două cercetări

b. Lucrurile care îi nemulţumesc pe părinţi în relaţia cu fiul/fiica lor

\begin{tabular}{|l|l|l|}
\hline Lucruri care nemulțumesc & $\begin{array}{l}\mathbf{2 0 1 1} \\
\mathbf{\%}\end{array}$ & $\begin{array}{l}\mathbf{2 0 1 6} \\
\mathbf{\%}\end{array}$ \\
\hline comunicare redusă/timp puţin & 4,27 & 24 \\
\hline Nu învață & 5,69 & 10,7 \\
\hline calculator & 5,31 & 10,9 \\
\hline minciuna & 4,4 & 7,2 \\
\hline
\end{tabular}

Tabelul 5 Prezentare comparativă a răspunsurilor întrebării nr. 9 a celor două cercetări

Aici apar diferenţe vizibile în cercetarea din 2016, care sunt în contradicție cu răspunsurile date la întrebarea 8 dar şi însuşirile alese de părinţi la întrebarea 3 . O explicaţie ar fi că părintele nu îşi cunoaşte copilul, e destul de ocupat, iar educaţia o plasează în responsabilitatea şcolii.

În ceea ce priveşte importanţa disciplinelor de învăţământ în formarea şi dezvoltarea caracterului unui copil - întrebarea nr. 10 alegerile părinţilor sunt redate în figura 11. 


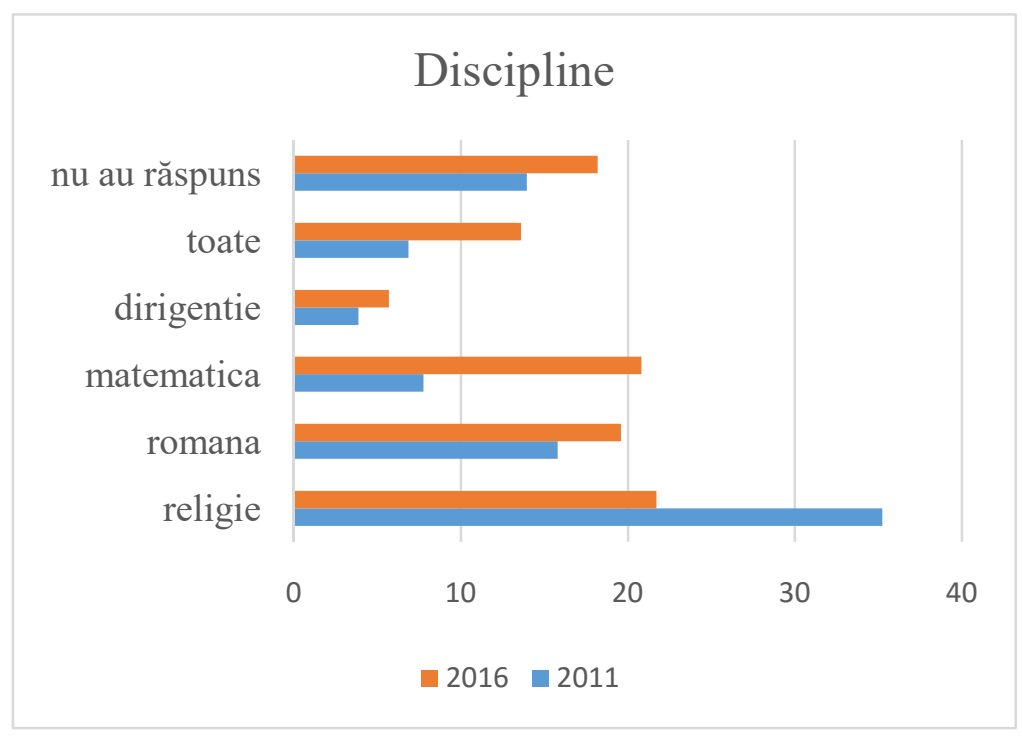

Fig. 6 Prezentare comparativă a răspunsurilor întrebării nr. 10 a celor două cercetări

În ambele cercetări, religia apare ca fiind disciplina care contribuie la modificarea comportamentului copilului, la întărirea credinţei şi la dezvoltarea iubirii faţă de semeni: 


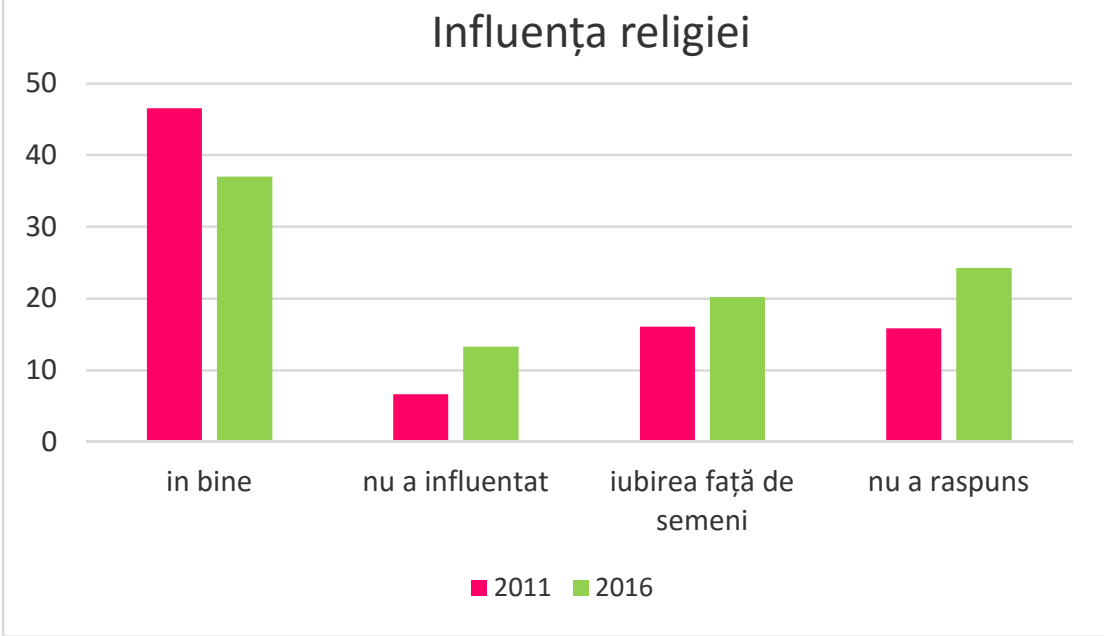

Fig. 7 Prezentare comparativă a răspunsurilor întrebării nr. 11 a celor două cercetări

Cercetarea noastră a mai reliefat prin răspunsurile date la întrebarea nr. 12 un aspect deosebit de important, legat de dorinţa părinţilor de a participa împreună cu proprii copii la activităţi organizate de şcoală de tipul: excursii, voluntariat, dezvoltare personală. Procentele sunt apropiate, cei mai mulţi dintre părinţi doresc să participe.

\begin{tabular}{|l|l|l|}
\hline $\begin{array}{l}\text { Activităţi organizate } \\
\text { de şcoală }\end{array}$ & $\begin{array}{l}\mathbf{2 0 1 1} \\
\mathbf{\%}\end{array}$ & $\begin{array}{l}\mathbf{2 0 1 6} \\
\mathbf{\%}\end{array}$ \\
\hline $\mathrm{da}$ & 70,2 & 67,63 \\
\hline $\mathrm{nu}$ & 36,16 & 29,76 \\
\hline
\end{tabular}

Tabelul 6 Prezentare comparativă a răspunsurilor întrebării nr. 12 a celor două cercetări

Din întrebarea nr. 13 reiese un alt aspect ce a avut în vedere opţiunea părinţilor privind alegerea de către aceştia a unei persoane 
potrivite pentru a-1 sprijini pe fiul/fiica lor în rezolvarea anumitor probleme:

\section{Spre cine ați îndruma copilul?}

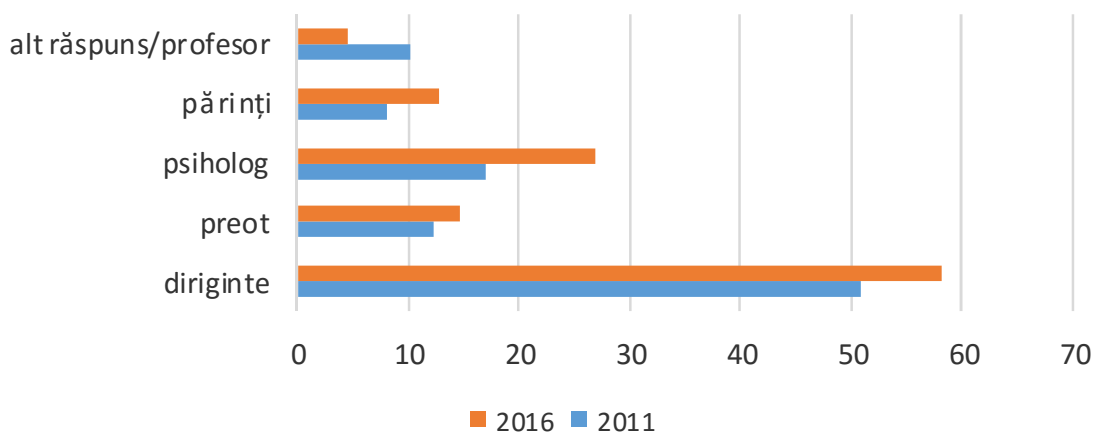

Fig. 8 Prezentare comparativă a răspunsurilor întrebării nr. 13 a celor două cercetări

Din analiza diagramei reiese că, în ambele cercetări, tot şcoala este preferată pentru rezolvarea problemelor, dirigintele beneficiind de încrederea părinţilor, urmat de psiholog şi preot. În 2016 a crescut şi procentul părinţilor care se consideră potriviţi în a-şi ajuta copilul $(12,71 \%)$, indicând o mică modificare a relaţiei părinţi - copii.

Răspunsurile sunt explicate parţial şi prin faptul că peste $50 \%$ dintre părinţi petrec puţin timp cu copiii lor. Motivele cel mai des invocate sunt legate de lipsa timpului şi oboseala, aşa cum sunt prezentate în tabelul comparativ.

\begin{tabular}{|l|l|l|}
\hline Răspunsuri & $\mathbf{2 0 1 1}$ \% & $\mathbf{2 0 1 6}$ \% \\
\hline petrec timp, nu caut scuze & 27,2 & 29,2 \\
\hline nu am timp & 45,46 & 33,2 \\
\hline oboseala & 11,01 & 9,8 \\
\hline alte răspunsuri & 7,27 & 9,6 \\
\hline
\end{tabular}

Tabelul 7 Prezentare comparativă a răspunsurilor întrebării nr. 14 a celor două cercetări 
Procentul de părinţi care lasă totul pentru a-şi petrece timpul cu copiii lor este de $27,20 \%$ apropiat de cel al părinţilor care îşi petrec câteva ore cu ei 24,22 în cercetarea din 2011. În cercetarea din 2016 procentul de părinţi care lasă totul pentru a-şi petrece timpul cu copiii lor este de 29,2\% - mai mare decât în 2011 - însă mult mai apropiat de cel al părinţilor care petrec zilnic câteva minute cu ei 32,4\%

O analiză a răspunsurilor la întrebările nr. 1 şi nr. 10 relevă faptul că părinţii, indiferent dacă îşi cunosc sau nu copilul, aleg religia drept disciplina care contribuie la cel mai înalt nivel la dezvoltarea caracterului.

a.

Răspunsul Da

b.

Răspunsul Nu

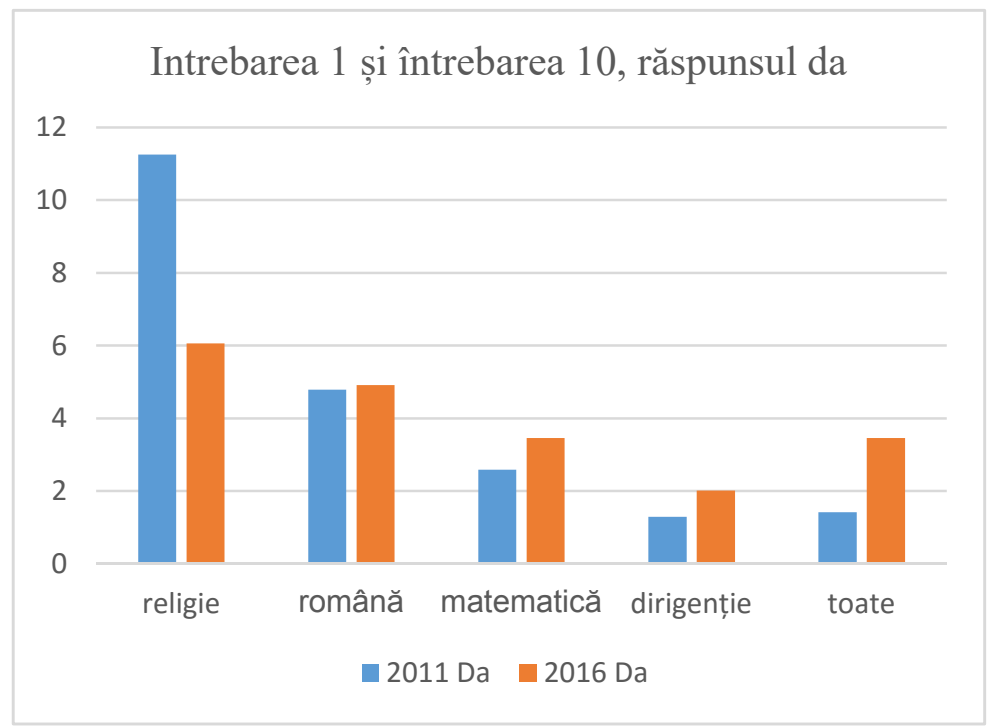

Fig. 9 Prezentare comparativă a răspunsurilor întrebării nr. 1 şi întrebarea nr. 10 a celor două cercetări: răspunsul Da la expresia "Părinții nu își cunose copiii" și "Care dintre materiile pe care le studiază fiul/ fiica dumneavoastră contribuie în cea mai mare măsură la modificarea în bine a comportamentului lui/ei?" 


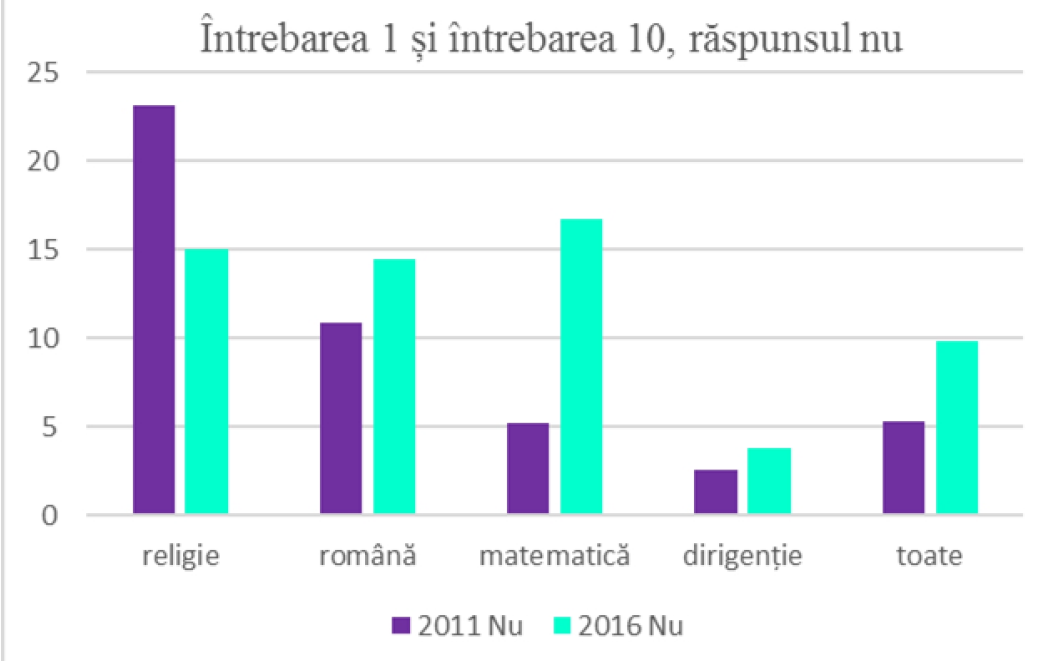

Fig. 10 Prezentare comparativă a răspunsurilor întrebării nr. 1 şi întrebarea nr. 10 a celor două cercetări, răspunsul $\mathrm{Nu}$ la expresia "Părinţii nu îşi cunosc copiii" și " Care dintre materiile pe care le studiază fiul/ fiica dumneavoastră contribuie în cea mai mare măsură la modificarea în bine a comportamentului lui/ei?"

În ceea ce priveşte alegerea persoanei care îi poate ajuta în rezolvarea problemelor (analiza întrebărilor nr. 1 şi nr. 13), indiferent de răspunsul dat la întrebarea nr. 1, se regăseşte aceeaşi distribuţie a răspunsurilor pentru întrebarea nr. 13, dirigintele fiind principalul sprijin identificat de părinţi pentru rezolvarea problemelor copiilor lor.
a. Răspunsul nu
b. Răspunsul da 


\section{Persoană}

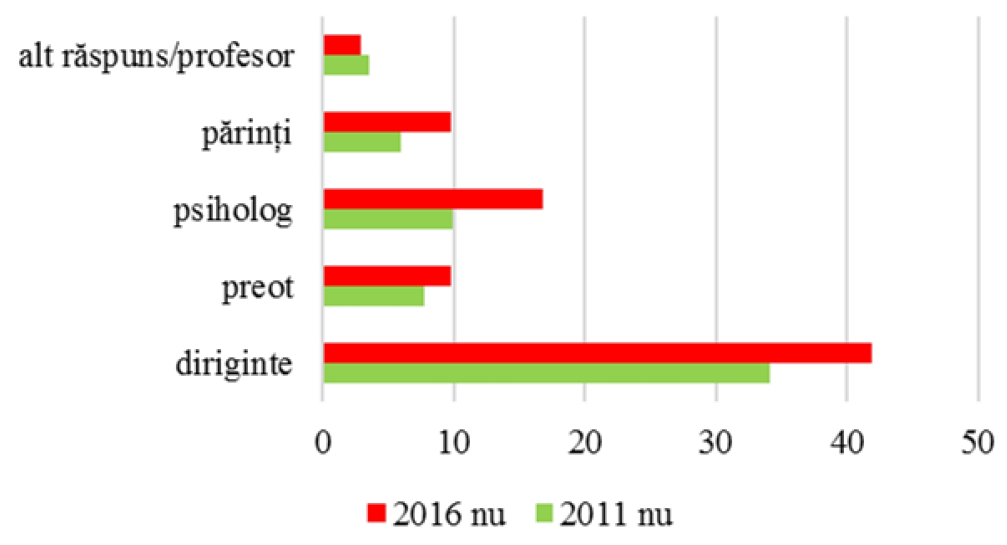

Fig. 11 Prezentare comparativă a răspunsurilor întrebării nr. 1 şi întrebarea nr. 13 a celor două cercetări, răspunsul Nu la expresia "Părinţii nu îşi cunosc copiii" și " Dacă fiul/ fiica dumneavoastră ar avea o problemă, spre cine l-aţi îndrepta să îl/ o îndrume?" 


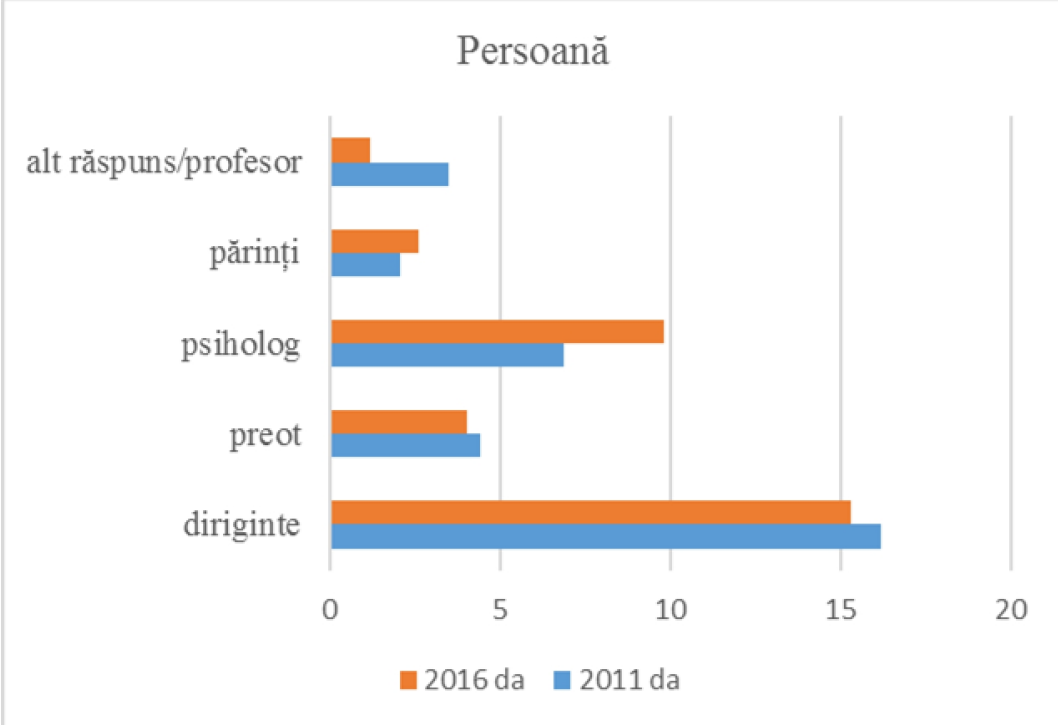

Fig. 12 Prezentare comparativă a răspunsurilor întrebării nr. 1 şi întrebarea nr. 13 a celor două cercetări, răspunsul Da la expresia "Părinţii nu îşi cunosc copiii!" și " Dacă fiul/ fiica dumneavoastră ar avea o problemă, spre cine l-aţi îndrepta să îl/ o îndrume?"

Din graficele de mai sus reiese că profesorii sunt apreciaţi de către părinţi, că la şcoală se abordează teme care îi pregătesc pe tineri pentru viaţă, dar în acelaşi timp şi faptul că le părinţii le acordă puţin timp copiilor. 


\section{Concluzii}

Părinţii elevilor de azi recunosc faptul că a fi părinte nu este un lucru deloc uşor, nevoia de implicare cu toată ființa în educarea copilului este tot mai mare, pe măsură ce societatea devine tot mai deschisă şi accesul la informaţie tot mai facil. Este foarte bine înţeleasă expresia: „Nimic nu poate înlocui educaţia primită acasă”, chiar şi în cazurile când timpul alocat în familie educaţiei copiilor este redus. Şcoala completează, desăvârşeşte educaţia religios-morală primită în familie, aducând o notă distinctivă în planul educaţiei intelectuale.

Diferenţele de opinii dintre părinţi şi copii au existat întotdeauna, indiferent de societatea în care trăim. Copiii de azi vor să fie independenţi, pe fondul preocupării părinţilor pentru siguranţa locului de muncă, pentru stabilitatea financiară. Acesta ar putea fi unul din motivele pentru care părinţii lasă uneori educaţia copiilor mai mult în seama şcolii.

Relaţia cu fiul / fiica trebuie să se bazeze pe încredere, sinceritate, să fie profundă - să nu urmărească doar aspectele materiale ale vieţii, ci şi gândurile, dorinţele, temerile, bucuriile lor, căci educaţia face diferenţa între oameni. Părinţii se arată preocupaţi de întărirea relaţiilor afective din cadrul familiei, pe baza iubirii faţă de copii, cu intenţia explicită de a-i susţine pe aceştia pentru a avea performanţe şi succes în viaţă. Acestea sunt incerte însă, mai ales în cazurile în care părinţii recunosc faptul că nu-şi cunosc foarte bine copiii.

$\mathrm{Nu}$ este deloc omis rolul religiei în educarea copiilor, care, aşa cum precizează şi părinţii în răspunsurile lor din chestionar, îi face pe copii mai buni, mai respectuoşi, mai responsabili.

Diferenţele procentuale care apar între cele două cercetări, realizate în anii 2011 şi 2016 pe baza aceluiaşi instrument de cercetare pun în evidenţă îndeosebi dorinţa părinţilor de a schimba ceva în relaţia cu propriul copil, dorinţa de a-i da acestuia o educaţie sănătoasă. 
Totodată, şcoala poate să vină în întâmpinarea părinţilor printr-un set de activităţi comune, care ar putea cuprinde: discuţii individuale / consiliere psihologică şi pastorală, lectorate cu părinţii, la care să fie invitate persoane specializate în educaţia adolescenţilor (preot, psiholog şcolar), realizarea unor activităţi ce vor urmări dezvoltarea abilităţilor de comunicare a părinţilor, participarea părinţilor, alături de copii, la activităţi extraşcolare desfăşurate de şcoală, activităţi cu elevii, ce vor urmări dezvoltarea unui stil de viaţ̧ă sănătos, armonios, precum şi de autocunoaştere a potenţialului şi capacităţilor personale (în special prin implicarea preotului, profesorului de religie, psihologului/consilierului şcolar).

Pentru o educaţie de bună calitate este nevoie deopotrivă de familie şi de şcoală, de colaborarea eficientă a celor doi factori pentru ca elevul/copilul să se simtă în siguranţă dar şi apreciat. 


\section{CHESTIONAR ADMINISTRAT PĂRINŢILOR}

Veţi găsi mai jos câteva întrebări referitoare la anumite aspecte legate de relaţia dumneavoastră cu fiul/ fiica dumneavoastră, care v-a adus acest chestionar. Nu există răspunsuri bune sau răspunsuri rele la aceste întrebări. Trebuie să vă exprimaţi cu sinceritate punctul de vedere referitor la problemele semnalate. Vă asigurăm că răspunsurile la întrebări sunt confidenţiale, de aceea nu vă cerem să vă scrieţi numele pe chestionar.

Cum completaţi chestionarul? - Scrieţi răspunsul în spaţiul prevăzut/ Completaţi datele în funcţie de cerinţa din întrebare/ Încercuiţi varianta aleasă de dumneavoastră/ Notaţi cu X varianta aleasă etc.

1. În ultimul timp se aude tot mai des expresia: "Părinţii nu îşi cunosc copiii". În ceea ce vă priveşte, o consideraţi adevărată?

$\square \mathrm{Da} \quad \square \mathrm{Nu}$ Motivaţi răspunsul ales

2. Notaţi cu $\mathbf{X}$ cinci din întrebările de mai jos, pe care le adresaţi cel mai des fiului/ fiicei dumneavoastră?

Thi-e foame?

Ce note ai luat astăzi?

Ai învăţat pentru mâine?

Ce s-a mai întâmplat în serialul pe care îl urmăreşti?

Unde te duci? Cu cine te întâlneşti? Cât stai?

Te-ai rugat astăzi?

De ce eşti supărat/ vesel?

Ai nevoie să te ajut la ceva?

De ce nu mă asculţi?

Cum te mai înțelegi cu colegii?

Vrei să discutăm?

De ce nu îmi spui adevărul?

Altă întrebare:

3. Alegeţi din lista de mai jos, trei dintre însuşirile care sunt cele mai evidente la fiul/ fiica dumneavoastră (Vă rugăm să le notaţi cu I, II, III, în ordinea importanţei):

politețea

credinţa

respectul

bunătatea

rugăciunea

curajul

cumpătarea

cuminţenia

sinceritatea

simţul umorului 
hărnicia conştiinciozitatea curajul

cumpătarea

4. Simţiţi nevoia să vă informaţi suplimentar despre ceea ce se întâmplă în viaţa fiului/ fiicei dumneavoastră?

$\square \mathrm{Da}$

$\square \mathrm{Nu}$

Care este motivul?

5. Cât de mult alocaţi din timpul dumneavoastră liber pentru a-l petrece doar cu fiul/ fiica dumneavoastră?

zilnic, câteva minute zilnic, câteva ore la sfârşit de săptămână doar atunci când mă solicită

Ce activităţi desfăşuraţi în acest timp?

6. Ştiţi cum îşi petrece fiul/ fiica dumneavoastră timpul liber?

Da, în măsura în care îmi spune el/ ea

Da, în măsura în care aflu de la alţii acest lucru

$\mathrm{Nu}$, pentru că am încredere în el/ea şi nu întreb

$\mathrm{Nu}$, pentru că oricum nu îmi spune adevărul

7. Care credeţi că este principalul motiv ce îi îndepărtează pe copii de părinţii lor, pe măsură ce cresc?

8. Scrieţi trei lucruri care vă mulţumesc în relaţia cu fiul/ fiica dumneavoastră.

1.

2.

3.

9. Scrieţi trei lucruri care vă nemulţumesc în relaţia cu fiul/ fiica dumneavoastră.

1 .

2.

3.

10. Care dintre materiile pe care le studiază fiul/ fiica dumneavoastră contribuie în cea mai mare măsură la modificarea în bine a comportamentului lui/ei?

Motivaţi alegerea făcută: 
11. Notaţi în spaţiul de mai jos modul în care consideraţi că disciplina religie a influenţat până acum viaţa/ comportamentul fiul/ fiicei dumneavoastră:

12. Aţi fi dispus/ă să participaţi la activităţi organizate de şcoală în comun cu fiul/ fiica dumneavoastră?

$\square \mathrm{Da}$

$\square \mathrm{Nu}$

Dacă $D a$, la ce activităţi?

13. Dacă fiul/ fiica dumneavoastră ar avea o problemă, spre cine 1-aţi îndrepta să îl/ o îndrume?

diriginte

profesorul/ profesoara de

preot

psiholog

altă persoană

14. Care este scuza dumneavoastră utilizată cel mai des atunci când fiul/ fiica dumneavoastră vă solicită să vă petreceţi timpul cu ei?

DATE DE IDENTIFICARE:

Vârsta:

ani

Genul: $\square$ feminin $\square$ masculin

Număr copii: __ fete __ băieţi

Ultima şcoală absolvită: $\square$ Şcoală clasele I-VIII $\square$ liceu

$\square$ şcoală profesională $\square$ facultate

Starea civilă: $\square$ căsătorit $\square$ divorţat $\square$ necăsătorit

Rezidența (unde locuiți): $\square$ urban/ oraş $\square$ rural/ comună, sat

Vă mulţumim! 


\section{Bibliografie}

1. Bocoş, M., Opriş, D. şi Opriş, M., Cercetarea în domeniul educaţiei religioase şi al educaţiei morale, Cluj-Napoca, Casa Cărţii de Ştiinţă, 2006.

2. Bulacu, Pr. Mihail, Pedagogie creştin-ortodoxă, Constanţa, Şcoala Brâncovenească, 2009.

3. Dumitru, Ion Al., Consiliere pedagogică. Baze teoretice şi sugestii practice, Iaşi, Editura Polirom, 2008.

4. Fântână, Ana, Relaţia părinţi-copii, incotro? Analiza rezultatelor unei cercetări pe bază de chestionar administrat părinţilor, în Monica Opriş (coord), „Demersuri investigative în educaţia religioasă”, Alba Iulia, Editura Reîntregirea, 2010.

5. Mucchielli, Alex, Arta de a comunica, Iaşi, Editura Polirom, 2005.

6. Nicola, Ioan, Tratat de pedagogie şcolară, Bucureşti, Editura Didactică şi pedagogică, 1996.

7. Opriş, M., Opriş, D., Cercetare şi religie, repere şi demersuri comune, Cluj-Napoca, Editura Eikon, 2013. 